\title{
Modelling and analysis of some parameters of thermal cycle of IC engine with EGR
}

\begin{abstract}
The results of modelling of thermal cycle of spark ignition internal combustion engine with exhaust gas recirculation are presented. Results of the impact of EGR on the emission of NO in the exhaust and heat release rate are presented. The optimization of thermal cycle was carried out in terms of ignition advance angle in order to obtain the possible highest value of efficiency and the least NO emission. Optimizing the engine cycle, a compromise between the thermodynamic parameters of cycle and emissions can be reached.
\end{abstract}

Key words: engine, emission, modelling, exhaust gas recirculation

\section{Modelowanie i analiza wybranych parametrów obiegu cieplnego silnika tlokowego z EGR}

W pracy przedstawiono wyniki modelowania obiegu cieplnego tłokowego silnika spalinowego z recyrkulacja spalin. Przedstawiono wyniki wptywu EGR na emisję NO oraz szybkość wydzielania ciepła. Przeprowadzono optymalizacje obiegu silnika pod względem kąta wyprzedzenia zapłonu w celu osiagnięcia możliwie największej wartości sprawności obiegu przy niskiej emisji NO. Optymalizując cykl silnika, uzyskano kompromis między parametrami termodynamicznymi obiegu a osiagana emisja spalin.

Słowa kluczowe: silnik, toksyczność spalin, modelowanie, recyrkulacja spalin

\section{Introduction}

Engines are designed to minimizing exhaust emissions while maximize power and economy. Emissions can be reduced by equipping the engine with advanced exhaust aftertreatment systems, or by controlling the combustion process occurring in the cylinder of internal combustion engine. One of possible methods which make possible to reduce of exhaust emission is exhaust gas recirculation. A fraction of the engine exhaust gases is recycled to the intake to dilute fresh mixture for control of $\mathrm{NO}_{x}$ emission [6]. This method is called exhaust gas recirculation (EGR). The recycled gases reduce the in-cylinder temperature and a decrease in knocking tendency. Exhaust gas recirculation is an effective way to reduce $\mathrm{NO}_{\mathrm{x}}$ in exhaust. An analysis of the literature suggests that in practice, are used two types of exhaust gas recirculation. One is called the hot EGR, in which the hot exhaust gases are delivered to intake manifold. The second type is cooled EGR, when the gas cooler system is applied. The exhaust gases supplied to the inlet system are cooled. Modelling and testing of engines in order to minimize their adverse impact on the environment are carried out by many researchers, as evidenced by, inter alia, the work $[1,4-7,9$, 10]. The ignition processes strongly affect the overall performance in spark ignition engines. Thermal efficiency and the level of $\mathrm{NO}_{x}$ emission are strongly influenced by ignition timing. Advancing the ignition timing causes the combustion process to occur earlier in the engine thermal cycle which leads to increased peaks of pressure and temperature during the combustion process. This is because of most of the fuel is burned before top dead center (TDC). Advancing the ignition timing, makes the combustion process occur near to TDC which is the ideal crank angle for combustion [17]. Advanc-

\section{Wstęp}

Silniki są tak budowane, aby osiągać jak największe osiągi przy minimalnej emisji zanieczyszczeń. Emisja toksycznych składników spalin może być ograniczona dzięki wyposażeniu silnika w zaawansowane układy oczyszczania spalin lub przez kontrolowanie procesu spalania zachodzącego w cylindrze tłokowego silnika spalinowego. Jednym z możliwych rozwiązań ograniczających emisję toksycznych składników spalin jest recyrkulacja spalin. Część spalin jest zawracana do układu dolotowego silnika w celu kontroli emisji $\mathrm{NO}_{\mathrm{x}}$ [6]. Metoda ta jest nazywana recyrkulacją spalin (EGR). Recyrkulowane gazy wylotowe ograniczają temperaturę w cylindrze oraz spalanie stukowe. Recyrkulacja spalin jest efektywną metodą do redukcji $\mathrm{NO}_{\mathrm{x}}$ w spalinach. Na podstawie literatury można stwierdzić, że $\mathrm{w}$ praktyce są wykorzystywane dwie metody recyrkulacji spalin. Jedna jest nazywana gorącym EGR - gdy do układu dolotowego kierowane są gorące spaliny. Druga jest nazywana zimnym EGR - w systemie recyrkulacji jest zastosowana chłodnica spalin. Doprowadzane spaliny do układu dolotowego są schłodzone. Wielu badaczy prowadziło badania zarówno modelowe, jak i eksperymentalne niekorzystnego wpływu silników spalinowych na środowisko naturalne, między innymi w pracach $[1,4-7,9,10]$. Proces zapłonu ma istotny wpływ na parametry pracy silnika tłokowego. Kąt wyprzedzenia zapłonu silnie wpływa na sprawność obiegu silnika oraz na poziom emisji $\mathrm{NO}_{\mathrm{x}}$. Przyspieszanie kąta wyprzedzenia zapłonu powoduje wcześniejsze inicjowanie procesu spalania w cyklu silnika, co powoduje zwiększenie maksymalnego ciśnienia i temperatury. Spowodowane jest to spalaniem większości paliwa przed GMP. Przyspieszanie kąta wyprzedzenia zapłonu powoduje zachodzenie procesu 
ing the ignition timing for a lean air-fuel mixtures causes the combustion process to occur earlier in the thermal cycle, which results in higher peak pressures and temperatures, what is the reason of higher rates of $\mathrm{NO}_{\mathrm{x}}$ formation. The high level of $\mathrm{NO}_{x}$ concentration is believed to be caused by the increase of peak temperature and a high oxygen concentration. Sasaki and coworkers [10] have investigated the impact of amount of EGR on the direct injection gasoline engine performance. They reported that according to the increase of EGR rate, the combustion at the late period was hastened in spite of reduction of the initial burning rate. In consequence, both $\mathrm{HC}$ and $\mathrm{NO}_{\mathrm{x}}$ were reduced by EGR [10]. They found that an appropriate volume of EGR improves fuel economy and $\mathrm{HC}$ emission. This phenomenon is presumably due to the intake temperature increase by EGR, which improved the flame propagation in the relatively lean area of the airfuel mixture. The limit to the share of EGR is presumably because of the worsened flame propagation associated with reduced oxygen concentration [10].

Abda-Alla [1] in their work has presented results of impact of EGR on the emission of SI engine. He stated that the effect of EGR on engine performance and efficiency, for mixtures with $\lambda>1$, is similar to the addition of excess air ratio. Both EGR and excess air dilute the unburned mixture. EGR also reduces the combustion rate, which makes stable combustion more difficult to achieve. At constant burn duration and brake mean affective pressure, the brake specific fuel consumption (BSFC) decreases with increasing EGR [1]. Cha [5] and all have studied the EGR system to reduce nitrogen oxides emission, to improve fuel economy and suppress knock by using the characteristics of charge dilution. The optimum EGR rate should be carefully determined in order to obtain the better engine performance and emissions. They found that the engine power decreased with EGR rate, and increased as the spark timing is advanced. As EGR rate increases, the spark timing of maximum engine power would be advanced. This means that optimum spark timing for engine power and fuel economy depends on the EGR rate [5]. Ibrahim and Bari [7] have studied a natural gas sparkignition engine employing cooled exhaust gas recirculation (EGR) strategy in a high pressure inlet condition. A two-zone combustion model was developed to simulate the in-cylinder conditions during combustion. It was found that the value of the compression ratio at which the minimum fuel consumption occurs varies with the engine speed. Cooled EGR has the potential on reducing the maximum burned gas temperature and consequently $\mathrm{NO}$ emission at high compression ratio conditions [7].

The paper presents the modelling results of thermal cycle of internal combustion engine with exhaust gas recirculation and an impact of EGR on NO emission and heat release rate.

\section{Modelling results}

Modelling of the thermal cycle of the test SI engine using the FIRE software was conducted. As the research object was taken internal combustion spark ignition test engine S320ER, operated at constant rotational speed equal to $1000 \mathrm{rpm}$. The spalania blisko GMP, a to położenie jest idealne dla procesu spalania [17]. Zwiększanie kąta zapłonu w silniku spalającym mieszanki ubogie powoduje wcześniejsze inicjowanie procesu spalania w cyklu, którego efektem jest zwiększenie wartości szczytowych ciśnienia i temperatury, a to jest przyczyną powstawania większej ilości $\mathrm{NO}_{\mathrm{x}} \mathrm{w}$ spalinach. Uważa się, że poziom emisji NO zależy od wartości maksymalnej temperatury w cyklu silnika oraz od koncentracji tlenu w komorze spalania. Sasaki ze współpracownikami [10] badali wpływ wartości EGR na osiągi silnika z wtryskiem bezpośrednim. Stwierdzili oni, że zwiększając udział EGR, mimo zmniejszenia początkowej szybkości spalania, uzyskano zwiększoną szybkość spalania w końcowej fazie procesu. W konsekwencji zarówno $\mathrm{HC}$, jak i NO zostały zredukowane przez EGR [10]. Stwierdzili oni także, że odpowiednia wartość EGR zmniejsza zużycie paliwa oraz emisję HC. Zjawisko to jest prawdopodobnie spowodowane wzrostem temperatury świeżego ładunku przez EGR, co poprawia warunki do rozprzestrzeniania się płomienia w relatywnie ubogim obszarze mieszanki paliwowo-powietrznej. Ograniczenie udziału EGR jest spowodowane pogorszeniem warunków propagacji płomienia wywołane ograniczoną koncentracją tlenu w komorze spalania [10].

Abda-Alla [1] w swojej pracy zaprezentował wyniki wpływu EGR na emisję silnika ZI. Stwierdził, że wpływ EGR na osiągi silnika oraz sprawność dla mieszanek o $\lambda>1$ jest podobny do powodowanego zubażaniem mieszanki. Zarówno EGR, jaki i zwiększanie współczynnika nadmiaru powietrza zubaża mieszankę. EGR także zmniejsza szybkość spalania, co utrudnia osiąganie stabilnego procesu spalania. Przy stałej długości spalania i średnim ciśnieniu efektywnym jednostkowe zużycie paliwa (BSFC) maleje ze wzrostem udziału EGR [1]. Cha i inni [5] wykorzystywali recyrkulację spalin do ograniczania emisji tlenków azotu, zmniejszenia zużycia paliwa oraz ograniczenia spalania stukowego. Optymalny udział EGR powinien być dokładnie określony w celu uzyskania najlepszych parametrów silnika i emisji. Stwierdzili oni, że moc silnika maleje ze wzrostem udziału EGR, a wzrasta ze zwiększaniem kąta zapłonu. Ze wzrostem udziału EGR w celu osiągnięcia maksymalnych parametrów silnika należy przyspieszać zapłon. Znaczy to, że optymalny kąt zapłonu dla osiągnięcia największej mocy oraz najmniejszego zużycia paliwa zależy od udziału EGR [5]. Ibrahim i Bari [7] badali silnik ZI zasilany gazem ziemnym, wyposażony w system zimnego EGR w warunkach wysokiego ciśnienia w układzie dolotowym. Dokonali modelowania procesu spalania w cylindrze silnika modelem dwustrefowym. Stwierdzili, że wartość stopnia sprężania, przy którym występuje minimalne zużycie paliwa zależy od prędkości obrotowej silnika. Zimne EGR ma zdolność zmniejszania temperatury spalania i konsekwentnie emisji NO przy dużych stopniach sprężania [7].

W pracy przedstawiono wyniki modelowania obiegu cieplnego silnika z recyrkulacją spalin oraz wpływ EGR na emisję NO w spalinach oraz szybkość wydzielania ciepła. 
researches was conducted for a wide range of excess air ratio and EGR share, accepted by engine. During the model tests the cold EGR was used. During the experimental researches engine was characterized by a high tendency to knock. Optimizing the engine thermal cycle, the knock process was considered [13-15].

The percentage of exhaust gases recycled back to the engine intake (\%EGR) was calculated as a percentage of the total inlet mass flow rate as follows:

$$
\% \mathrm{EGR}=\frac{\dot{\mathrm{m}}_{\mathrm{EGR}}}{\dot{\mathrm{m}}_{\mathrm{a}}+\dot{\mathrm{m}}_{\mathrm{f}}+\dot{\mathrm{m}}_{\mathrm{EGR}}}
$$

where: $\dot{\mathrm{m}}_{\mathrm{EGR}}$ is mass rate of EGR, $\dot{\mathrm{m}}_{\mathrm{a}}$ is mass rate of air, $\dot{\mathrm{m}}_{\mathrm{f}}$ is mass rate of fuel respectively in $\mathrm{kg} / \mathrm{s}$.

One of the parameters determining the performance of the combustion process in the engine is the mean indicated pressure.

$$
\mathrm{p}_{\mathrm{i}}=\frac{\sum_{-180}^{180} \frac{\mathrm{p}_{\mathrm{n}}+\mathrm{p}_{\mathrm{n}+\mathrm{l}}}{2}\left(\mathrm{~V}_{\mathrm{n}+1}-\mathrm{V}_{\mathrm{n}}\right)}{\mathrm{V}_{\mathrm{s}}}
$$

where: $p_{n}, p_{n+1}$ are instantaneous values of the pressure in the cylinder $[\mathrm{MPa}], \mathrm{V}_{\mathrm{n}}, \mathrm{V}_{\mathrm{n}+1}$ are instantaneous values of the cylinder volume $\left[\mathrm{m}^{3}\right], \mathrm{V}_{\mathrm{s}}$ is displacement volume $\left[\mathrm{m}^{3}\right]$.

The average value of the indicated efficiency, expressed in $\%$ is equal to:

$$
\eta_{i}=\frac{p_{i} V_{s}}{Q} 100 \%
$$

where $\mathrm{Q}$ is total heat supplied to the engine $[\mathrm{MJ}]$.

The heat supplied to the engine cylinder:

$$
\mathrm{Q}=\frac{\mathrm{V} \rho \mathrm{W}}{0.5 \mathrm{nt}}
$$

where: $\mathrm{V}$ is volume of gasoline delivered to the engine cylinder $\left[\mathrm{m}^{3}\right], \rho$ is density of gasoline $\left[\mathrm{kg} / \mathrm{m}^{3}\right], \mathrm{W}$ is calorific value of gasoline $[\mathrm{MJ} / \mathrm{kg}], \mathrm{n}$ is speed engine $[\mathrm{rpm}], \mathrm{t}$ is time consumption of gasoline delivered to the engine cylinder [min].

Determined an engine efficiency is the gross efficiency, the modelling does not include charge exchange loop.

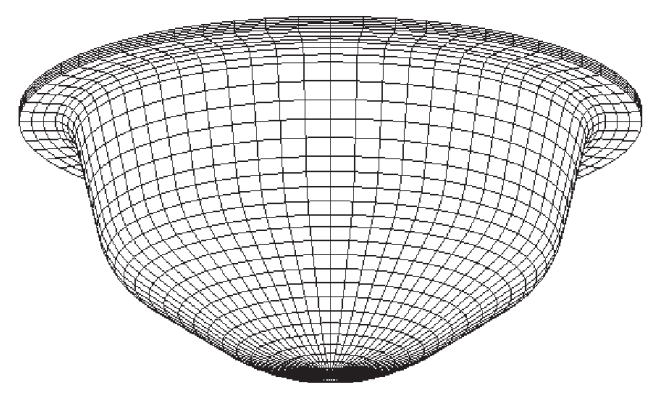

Fig. 1. The computational mesh for combustion chamber Rys. 1. Siatka obliczeniowa komory spalania

\section{Wyniki modelowania}

Modelowanie obiegu cieplnego silnika ZI przeprowadzono w programie FIRE. Jako obiekt badań wykorzystano badawczy tłokowy silnik spalinowy o zapłonie iskrowym S320ER. Silnik pracował ze stałą prędkością obrotową 1000 obr/min. Badania były prowadzone dla szerokiego zakresu współczynnika nadmiaru powietrza i udziału EGR, akceptowanego przez silnik. W czasie badań modelowych użyto zimny EGR. Podczas badań eksperymentalnych okazało się, że silnik charakteryzuje się dużą skłonnością do spalania stukowego. Podczas badań optymalizacyjnych brano pod uwagę ograniczający wpływ spalania stukowego [13-15].

Udział procentowy recyrkulowanych spalin do układu dolotowego silnika (\% EGR) był określany jako procent całkowitej masy dostarczanej do cylindra - wzór (1), gdzie: $\dot{\mathrm{m}}_{\mathrm{EGR}}$ - udział masowy EGR, $\dot{\mathrm{m}}_{\mathrm{a}}$ - udział masowy powietrza, $\dot{\mathrm{m}}_{\mathrm{f}}-$ udział masowy paliwa, odpowiednio $\mathrm{w} \mathrm{kg} / \mathrm{s}$.

Jednym z określanych parametrów charakteryzujących obieg cieplny silnika jest średnie ciśnienie indykowane, obliczane na podstawie zależności (2), gdzie: $\mathrm{p}_{\mathrm{n}}, \mathrm{p}_{\mathrm{n}+1}$ chwilowe wartości ciśnienia w cylindrze $[\mathrm{MPa}], \mathrm{V}_{\mathrm{n}}, \mathrm{V}_{\mathrm{n}+1}$ - chwilowe wartości objętości cylindra $\left[\mathrm{m}^{3}\right], \mathrm{V}_{\mathrm{s}}$ - objętość skokowa $\left[\mathrm{m}^{3}\right]$.

Wartość sprawności indykowanej, wyrażonej w \%, przedstawia wzór (3), gdzie: Q ciepło dostarczone w paliwie do silnika $[\mathrm{MJ}]$.

Ciepło dostarczone do cylindra silnika - wzór (4), gdzie: $\mathrm{V}$ - objętość paliwa dostarczona do cylindra silnika $\left[\mathrm{m}^{3}\right]$, $\rho$ - gęstość paliwa $\left[\mathrm{kg} / \mathrm{m}^{3}\right], \mathrm{W}$ - wartość opałowa benzyny [MJ/kg], n - prędkość obrotowa silnika [obr/min], t - czas zużycia dostarczonego paliwa do cylindra silnika [min].

Wyznaczoną sprawność silnika należy traktować jako wartość brutto, ponieważ nie uwzględniono pętli wymiany ladunku.

Badania modelowe (rys. 1) były prowadzone w programie FIRE [3]. Pierwszym etapem modelowania była kalibracja modelu przez porównywanie przebiegów ciśnienia uzyskanych modelowaniem z przebiegami uzyskanymi eksperymentalnie. Weryfikacja modelu była przeprowadzona zarówno dla warunków bez spalania stukowego, jak i ze spalaniem stukowym. Uzyskana satysfakcjonująca zgodność wyników modelowania $\mathrm{z}$ eksperymentem pozwoliła na przeprowadzenie zasadniczych badań modelowych. Wyniki weryfikacji modelu zaprezentowano w już opublikowanych i przyjętych do druku pracach [13-15].

Jako paliwo przyjęto węglowodór $\mathrm{C}_{8} \mathrm{H}_{17}$. Modelowanie procesu spalania przeprowadzono $\mathrm{z}$ wykorzystaniem modelu ECFM [3]. Ten model spalania bazuje na zjawisku turbulentnego mieszania strefy powietrza, paliwa i gazów spalinowych. Model ECFM został zbudowany z myślą o modelowaniu spalania w silniku o zapłonie iskrowym. Model ten umożliwia modelowanie spalania mieszanek paliwowo-powietrznych z EGR oraz tworzeniem NO. Opiera się on na opisie niespalonej i spalonej strefy ładunku. Koncepcja modelu spalania jest oparta na idei spalania laminarnego, gdzie prędkość i grubość frontu płomienia są określone średnią wartością na całej jego długości. Grubość 
Model tests (Fig. 1) were carried out in FIRE software [3]. The first stage of model calibration was comparing the courses of pressure taken from the real test engine with the course obtained by the FIRE software modelling. The verification was carried out for both conditions with and without knock combustion.

Satisfactory agreement of obtained results allowed to start fundamental modelling and some results are presented in this paper. Results of experimental verification of model are presented in the already published or accepted for printing articles [13-15].

As a fuel $\mathrm{C}_{8} \mathrm{H}_{17}$ hydrocarbon was taken. For modelling the combustion process used Extended Coherent Flame Model (ECFM) [3]. This combustion model is based on the phenomenon of turbulent mixing zone of air, fuel and exhaust. The ECFM has been developed in order to describe combustion process in spark ignition engines. This model allows the modelling of the combustion process of air-fuel mixtures with EGR effect and NO formation. The model relies on description of unburned and burnt zones of the gas. The concept of combustion model is based on a laminar flamelet idea, whose velocity and thickness are mean values, integrated along the flame front. The thickness of the layer of flame front depends on the pressure, the temperature and content of unburned fuel in the fresh zone. In addition, it is assumed that reaction takes place within relatively thin layers that separate the fresh unburned gas from the fully burnt gas. This model uses a 2-step chemistry mechanism for the fuel conversion.

$$
\begin{gathered}
2 \mathrm{C}_{8} \mathrm{H}_{17}+98 \mathrm{O}_{2} \rightarrow 14 \mathrm{CO}_{2}+17 \mathrm{H}_{2} 0 \\
2 \mathrm{C}_{8} \mathrm{H}_{17}+8 \mathrm{O}_{2} \rightarrow 16 \mathrm{CO}+17 \mathrm{H}_{2}
\end{gathered}
$$

The second reaction (6) of formation of $\mathrm{CO}$ and $\mathrm{H}_{2}$ is taken into account for stoichiometric and fuel-rich mixtures, while for lean mixtures this reaction is omitted. The unburned gas phase consists of 5 main unburned species: fuel, $\mathrm{O}_{2}, \mathrm{~N}$, $\mathrm{CO}_{2}$ and $\mathrm{H}_{2} \mathrm{O}$. The burnt gas phase it is assumed that no fuel remains. The burnt gas is composed of 11 species, such as $\mathrm{O}, \mathrm{O}_{2}, \mathrm{~N}, \mathrm{~N}_{2}, \mathrm{H}, \mathrm{H}_{2}, \mathrm{CO}, \mathrm{CO}_{2}, \mathrm{H}_{2} \mathrm{O}, \mathrm{OH}$ and NO. Modeling was carried out using the exhaust gas recirculation. For each share of EGR from 0 to $12.5 \%$ at $2.5 \%$ was also carried out optimization of ignition timing advance. An example of such optimization is shown in Fig. 2.

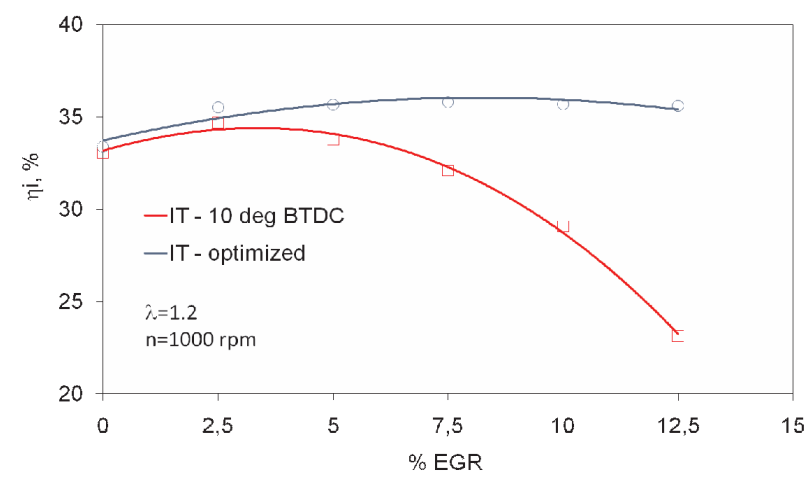

Fig. 2. Indicated thermal efficiency courses for $\lambda=1.2$ Rys. 2. Sprawność indykowana silnika dla $\lambda=1,2$ warstwy frontu płomienia zależy od ciśnienia, temperatury i zawartości niespalonego paliwa w strefie świeżego ładunku. Dodatkowo zakłada się, że reakcje zachodzą w relatywnie cienkiej warstwie, która oddziela gazy niespalone od już całkowicie spalonych. Model ten wykorzystuje dwustopniowy mechanizm spalania - reakcje (5) i (6).

Table 1. Modelling parameters

Tabela 1. Parametry modelowania

\begin{tabular}{|l|c|c|}
\hline \multicolumn{2}{|l|}{ Engine parameters/parametry silnika } & $1000 \mathrm{rpm}$ \\
\hline Engine rotational speed/prędkość obrotowa & - & $120 \mathrm{~mm}$ \\
\hline Cylinder bore/średnica cylindra & - & $160 \mathrm{~mm}$ \\
\hline Stroke/skok tłoka & - & $275 \mathrm{~mm}$ \\
\hline Connecting-rod length/dlugość korbowodu & - & $2 \mathrm{~mm}$ \\
\hline Squish/niedojście tłoka & - & 8.5 \\
\hline Compression ratio/stopień sprężania & - & \\
\hline Initial conditions/warunki początkowe & & $0.9 \mathrm{MPa}$ \\
\hline $\begin{array}{l}\text { Initial pressure for 180 deg BTDC/ciśnie- } \\
\text { nie początkowe dla 180o przed GMP }\end{array}$ & - & $310 \mathrm{~K}$ \\
\hline $\begin{array}{l}\text { Initial temperature for 180 deg BTDC/tem- } \\
\text { peratura początkowa dla 180 }{ }^{\circ} \text { przed GMP }\end{array}$ & - & - \\
\hline Lambda/współczynnik nadmiaru powietrza & - & $1.0-1.3$ \\
\hline EGR & - & $0-12.5 \%$ \\
\hline Fuel/paliwo & - & C $\mathrm{H}_{17}$ \\
\hline FIRE sub-models/podmodele FIRE & - & $\begin{array}{c}\text { Coherent Flame } \\
\text { Model ECFM }\end{array}$ \\
\hline Turbulence model/model turbulencji & - & dovich Model \\
\hline $\begin{array}{l}\text { Combustion model/model spalania } \\
\text { NO formation model/model NO }\end{array}$ \\
\hline Knock model/model spalania stukowego & - & - \\
\hline
\end{tabular}

Reakcja (6) tworzenia $\mathrm{CO} \mathrm{i}_{2}$ jest brana pod uwagę dla mieszanek stechiometrycznych oraz bogatych, dla mieszanek ubogich reakcja ta jest pomijana. Strefa niespalona mieszanki składa się z 5 głównych składników: paliwo, $\mathrm{O}_{2}, \mathrm{~N}, \mathrm{CO}_{2} \mathrm{i}$ $\mathrm{H}_{2} \mathrm{O}$. Zakłada się, że w strefie spalin nie ma paliwa. Spaliny składają się z 11 składników: $\mathrm{O}, \mathrm{O}_{2}, \mathrm{~N}, \mathrm{~N}_{2}, \mathrm{H}, \mathrm{H}_{2}, \mathrm{CO}, \mathrm{CO}_{2}$, $\mathrm{H}_{2} \mathrm{O}, \mathrm{OH}$ i NO.

W modelowaniu uwzględniono recyrkulację spalin. Dla wszystkich udziałów EGR od 0 do $12,5 \%$ co $2,5 \%$ przeprowadzono optymalizację kąta zapłonu. Przykład takiej optymalizacji przedstawiono na rys. 2 .

Dla niezmienianego kąta zapłonu 2,5-procentowy udział EGR spowodował wzrost sprawności indykowanej silnika badawczego. Dalsze zwiększanie wartości udziału EGR powodowało zmniejszanie wartości sprawności. Optymalizując kąt wyprzedzenia zapłonu, uzyskano wzrost sprawności indykowanej obiegu. Wraz ze wzrostem udziału EGR, optymalizacja kąta zapłonu powodowała wzrost różnicy w uzyskiwanych sprawnościach obiegu (rys. 2). Przy 12,5-procentowym udziale EGR nastąpił wzrost sprawności z około $23 \%$ do ponad $35 \%$. Jak już wspomniano, silnik ten ma skłonności do spalania stukowego. Prezentowane wyniki optymalizacji uzyskano dla warunków ograniczonych tym niekorzyst- 
For the unchanged conditions of ignition angle, 2.5\% of EGR led to increase the efficiency of the test engine. Further increase in the share values of EGR resulted in a decrease engine efficiency. By optimizing the angle of ignition, increase engine efficiency was achieved. With the increasing participation of EGR, the ignition angle optimization resulted in an increasing difference in the efficiencies obtained. For a $12.5 \%$ share of the EGR, increase the efficiency from about $23 \%$ to over $35 \%$ was achieved. As mentioned, the engine is prone to knock combustion. Presented results of efficiency were obtained for the conditions prior to the knock limit. Obtaining a higher value was limited occurrence of knock. In the following are presented the results of an optimized thermal cycle of the test engine.

Effects of the use of exhaust gas recirculation is preferably on the content of NO in the exhaust but also adversely affects of the thermodynamic parameters of thermal cycle engine. Optimizing the engine cycle in terms of the angle of ignition is achieved satisfactory thermodynamic parameters of the engine at relatively low values of $\mathrm{NO}$ in the exhaust. For $\lambda=$ 1.2 at $12.5 \%$ of EGR was achieved $7.8 \mathrm{~g} / \mathrm{kW} \cdot \mathrm{h}$ of NO in the exhaust, without exhaust gas recirculation it was $20.5 \mathrm{~g} / \mathrm{kW} \cdot \mathrm{h}$. At the same time increased the engine efficiency, but decreased mean indicated pressure from 0.82 to $0.73 \mathrm{MPa}$.

a)

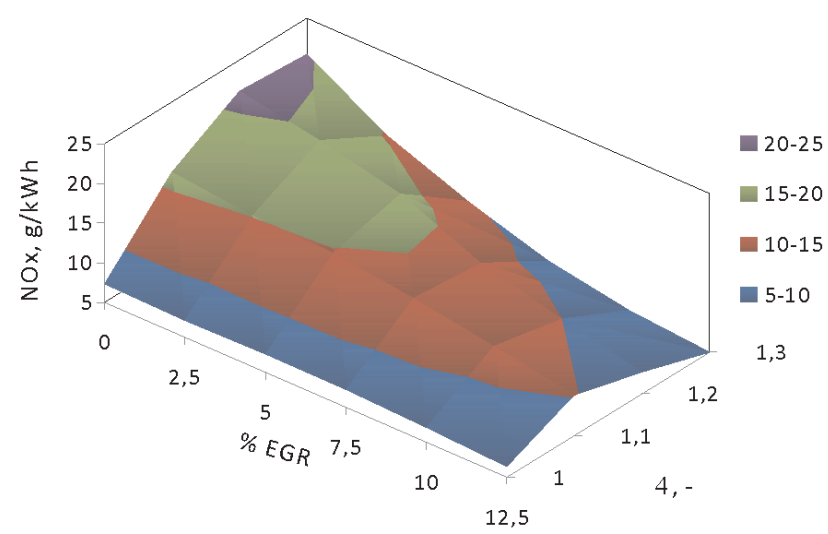

nym zjawiskiem. Uzyskanie wyższych wartości zostało ograniczone właśnie spalaniem stukowym. Poniżej przedstawiono wyniki optymalizacji obiegu cieplnego silnika badawczego.

Stosowanie recyrkulacji spalin korzystnie wpływa na zawartość NO w spalinach, ale jednocześnie niekorzystnie wpływa na parametry termodynamiczne obiegu cieplnego silnika. Optymalizując obieg silnika pod względem kąta zapłonu, uzyskuje się satysfakcjonujące parametry termodynamiczne silnika przy relatywnie niskiej emisji $\mathrm{NO} w$ spalinach. Dla $\lambda=1,2$ przy 12,5 -procentowym udziale EGR uzyskano zawartość NO 7,8\% $\mathrm{g} / \mathrm{kW} \cdot \mathrm{h}$, a bez recyrkulacji spalin było $20,5 \mathrm{~g} / \mathrm{kW} \cdot \mathrm{h}$. Jednocześnie wzrosła sprawność, ale zmniejszyła się wartość średniego ciśnienia indykowanego z 0,82 do $0,73 \mathrm{MPa}$.

Rysunek $3 b$ ilustruje wpływ kąta wyprzedzenia zapłonu na zawartość NO w spalinach. Wzrost zawartości tlenku azotu w spalinach jest oczywiście związany ze wzrostem temperatury w komorze spalania silnika. Ograniczeniem udziału EGR jest pogorszenie się warunków propagacji płomienia powiązane z mniejszą koncentracją tlenu w komorze spalania silnika. Wzrost zawartości recyrkulowanych spalin rozcieńcza mieszankę paliwowo-powietrzną, zmniejszając koncentrację tlenu, a w konsekwencji zmniejsza znacznie szybkość spalania.

b)

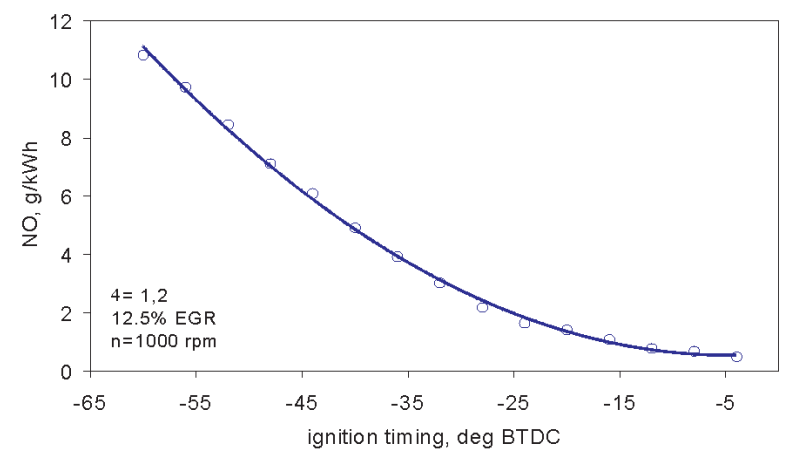

Fig. 3. The content of nitrogen oxides in the exhaust gas in optimized conditions (a) and impact of ignition angle on the NO content in the exhaust (b) Rys. 3. Zawartość tlenków azotu w spalinach, w warunkach zoptymalizowanych (a) $i$ wplyw kąta zapłonu na zawartość NO $w$ spalinach (b)

Figure $3 \mathrm{~b}$ shows the impact of spark advance angle on the exhaust emissions of NO. The increase in nitrogen oxide emissions is of course due to the increase of temperature in the combustion chamber.

The limit to the volume of EGR is the worsened flame propagation associated with reduced oxygen concentration in the combustion chamber. The increase of the percentage of EGR dilution in the air-fuel mixture decreases the oxygen concentration, and consequently, it decreases the combustion rate significantly.

Figure $4 \mathrm{a}$ shows the courses of the heat release rate obtained for excess air ratio equal to 1.2 , and different
$\mathrm{Na}$ rysunku 4a przedstawiono przebiegi szybkości wydzielania ciepła uzyskane dla współczynnika nadmiaru powietrza równego 1,2 i różnych udziałów EGR. Wzrost udziału recyrkulowanych spalin spowalnia proces spalania. Ze wzrostem udziału EGR maleje także szybkość wydzielania ciepła. Na rysunku $4 \mathrm{~b}$ przedstawiono przebiegi szybkości wydzielania ciepła w warunkach zoptymalizowanych. Dla warunków zoptymalizowanych obiegu cieplnego silnika, pod względem kąta wyprzedzenia zapłonu, krzywe szybkości wydzielania ciepła są skoncentrowane w podobnym przedziale kątowym obrotu wału korbowego. Przy udziale EGR do 
a)

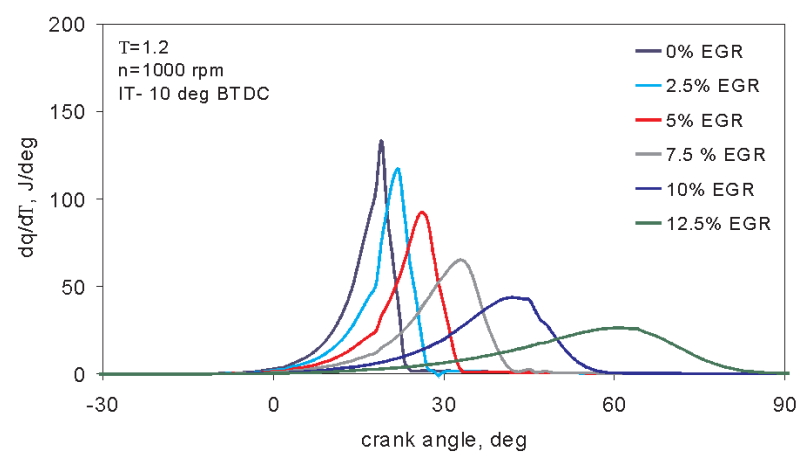

b)

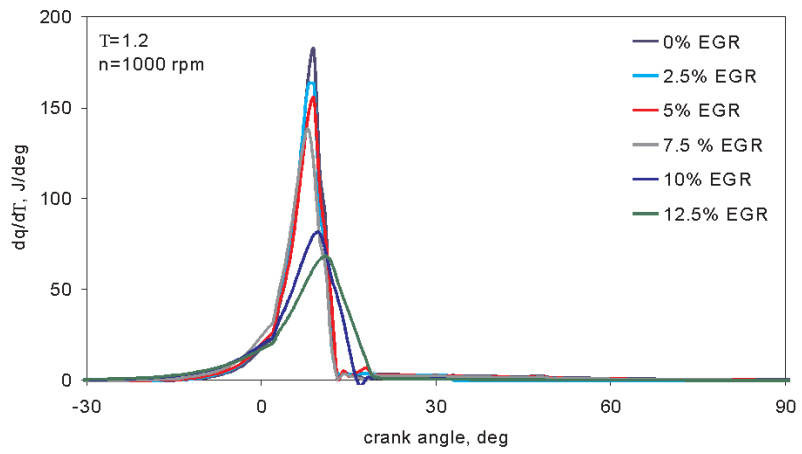

Fig. 4. The rate of heat release in the test engine obtained in conditions: constant ignition timing 10 deg BTDC (a) and optimized ignition timing (b) Rys. 4. Szybkość wydzielania ciepła w silniku badawczym w warunkach: niezmiennego kąta wyprzedzenia zapłonu $10^{\circ}$ OWK przed GMP (a) i przy zoptymalizowanym kacie zapłonu (b)

EGR shares. The increasing share of recirculated exhaust gases slows down the combustion process. With the increasing participation of EGR rate followed decrease the heat release rate. Figure $4 \mathrm{~b}$ shows courses of heat release rate for optimized conditions. For optimized thermal cycle of the test engine relative to ignition timing advance the rate of heat release curves are concentrated in a similar range of angles of crankshaft rotation. To participate to $7.5 \%$ of EGR, differences are practically only the value of $\mathrm{dq} / \mathrm{d} \varphi$. For the participation of $10 \%$ has already followed significant slowdown of the combustion process.

Figure 5 shows that optimizing the thermal cycle of engine with EGR resulted in a significant increase in the rate of heat release. With $12.5 \%$ share of the EGR was obtained 2.5 times of increase in rate of heat release $\mathrm{dq} / \mathrm{d} \varphi$, from 26.3 to $66 \mathrm{~J} / \mathrm{deg}$.

\section{Summary}

The paper presents the impact of exhaust gas recirculation on selected parameters of the thermal cycle of internal combustion spark ignition engine. The optimization of thermal cycle was carried out in terms of ignition advance angle in order to obtain the possible highest efficiency.

The modelling also included knock combustion process, which has limited possible to obtain the thermodynamic parameters of the test engine [13-15]. The engine was prone to knock combustion. Such a reaction engine to exhaust gas recirculation may be due to the specific shape of the combustion chamber. Earlier studies of author have shown that the in the studied combustion chamber the turbulence occurs at a very low level $[12,16]$.

A small share of the EGR (2.5\%), with a constant angle of ignition has increased the indicated efficiency of the test engine. The optimization of ignition angle resulted in an increasing of the efficiency, for example, for a $12.5 \%$ share of the EGR and $\lambda=1.2$, increase the efficiency from about $23 \%$ to over $35 \%$ was achieved. For $\lambda=1.2$ at $12.5 \%$ of EGR was achieved over 2.5 times decrease of NO concentrtion in exhaust. At the
$7,5 \%$ różnice występują praktycznie tylko w wartościach $\mathrm{dq} / \mathrm{d} \varphi$. Dla udziału od $10 \%$ nastąpiło już pewne wydłużenie procesu spalania

$\mathrm{Na}$ rysunku 5 przedstawiono wartości maksymalne szybkości wydzielania ciepła; optymalizację obiegu spowo-

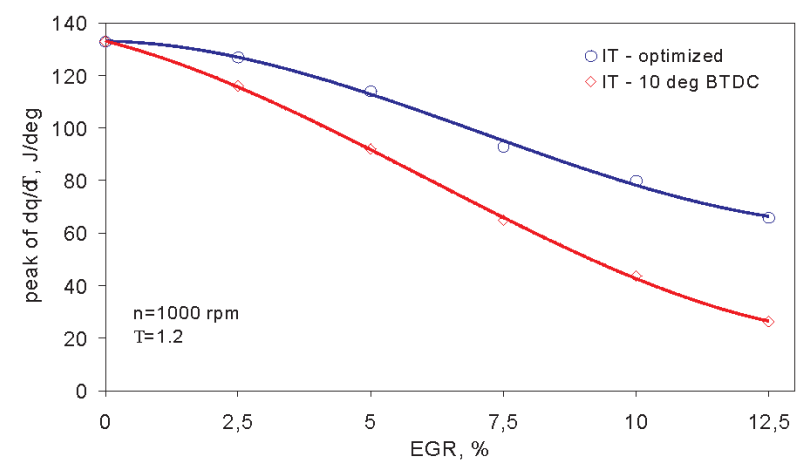

Fig. 5. Values of maximum heat release rates for excess air ratio equal to 1.2 and different shares of EGR

Rys. 5. Maksymalne wartości szybkości wydzielania ciepła dla wspótczynnika nadmiaru powietrza 1,2 i różnych udziałów EGR

dował znaczący wzrost szybkości wydzielania ciepła. Przy udziale EGR 12,5\% uzyskano 2,5-krotny wzrost szybkości wydzielania ciepła dq/d $\varphi$, z 26,3 do $66 \mathrm{~J} / \mathrm{deg}$.

\section{Podsumowanie}

W pracy przedstawiono wpływ recyrkulacji spalin na wybrane parametry obiegu cieplnego tłokowego silnika spalinowego. Przeprowadzono optymalizację obiegu silnika po względem kąta wyprzedzenia zapłonu w celu uzyskania możliwie największej sprawności. W modelowaniu uwzględniono także proces spalania stukowego, które ograniczało uzyskanie większych wartości parametrów termodynamicznych silnika badawczego [13-15]. Silnik ten miał skłonności do spalania stukowego. Taka reakcja silnika na recyrkulację spalin mogła być spowodowana specyficznym kształtem komory spalania. Wcześniejsze badania autora wykazały, że ta komora spalania charakte- 
same time increased the engine efficiency, but decreased mean indicated pressure over $25 \%$. With $12.5 \%$ share of the EGR was obtained 2.5 times of increase in rate of heat release. The best compromise between the indicated thermal efficiency and exhaust emission is reached at optimal ignition timing.

Exhaust gas recirculation is beneficial not only to reduce the toxicity of exhaust gases but it also strongly influences of the thermodynamic parameters of the engine, such as efficiency, the average indicated pressure, the rate of heat release and effectively shifts the formation of the knock limit.

\section{Acknowledgements}

The author would like to express their gratitude to AVL LIST $\mathrm{GmbH}$ for Providing a AVL Fire software under the University Partnership Program.

Paper reviewed/Artykut recenzowany ryzowała się bardzo niskim poziomem turbulencji ładunku $[12,16]$.

Mały udział EGR (2,5\%) przy stałym kącie wyprzedzenia zapłonu spowodował wzrost sprawności indykowanej silnika. Optymalizacja obiegu spowodowała wzrost sprawności silnika dla 12,5-procentowego udziału EGR i $\lambda=1,2$; nastąpił wzrost sprawności z $23 \%$ do ponad $35 \%$. Dla $\lambda=$ 1,2 i 12,5\% EGR uzyskano ponad 2,5-krotny spadek zawartość NO w spalinach. Przy 12,5-procentowym udziale EGR uzyskano także 2,5-krotny wzrost szybkości wydzielania ciepła. Najlepszy kompromis pomiędzy wartością sprawności indykowanej a emisją spalin uzyskano dla optymalnego kąta zapłonu. W tym samym czasie, gdy uzyskiwano wzrost sprawności, nastąpił spadek średniego ciśnienia indykowanego o ponad $25 \%$.

Recyrkulacja spalin nie tylko korzystnie wpływa na toksyczność spalin, ale także silnie wpływa na wartości parametrów termodynamicznych silnika, takie jak średnie ciśnienie indykowane, szybkość wydzielania ciepła i przesuwa granicę spalania stukowego.

\section{Bibliography/Literatura}

[1] Abd-Alla G.H.: Using exhaust gas recirculation in internal combustion engines: a review. Energy Conversion and Management 43, 2002.

[2] Amr I., Saiful B.: Optimization of a natural gas SI engine employing EGR strategy using a two-zone combustion model, Fuel 87, 2008.

[3] AVL FIRE, VERSION 2009ICE Physics \& Chemistry. Combustion, Emission, Spray, Wallfilm. Users Guide, 2009.

[4] Buomsik S., Youngsoo C., Daeha H., Soonho S., Kwang M. C.: Hydrogen effects on $\mathrm{NO}_{\mathrm{x}}$ emissions and brake thermal efficiency in a diesel engine under low-temperature and heavyEGR conditions. International Journal of Hydrogen Energy, Vol. 36, Issue 10, 2011.

[5] Cha J., Kwon J., Cho Y., Park S.: The Effect of Exhaust Gas Recirculation (EGR) on Combustion Stability, Engine Performance and Exhaust Emissions in a Gasoline Engine. KSME International Journal, Vol. 15, No. 10, 2001.

[6] Heywood J. B.: Internal Combustion Engine Fundamentals. New York: McGraw-Hill, 1988.

[7] Ibrahim A., Bari S.: Optimization of a natural gas SI engine employing EGR strategy using a two-zone combustion model. Fuel 87, 2008.

[8] Li J., Gong H., M., Su Y., Dou H.L., Liu X.J.: Effect of injection and ignition timings on performance and emissions

Wojciech Tutak, DEng. - doctor in the Faculty of Mechanical Engineering and Computer Science of Częstochowa University of Technology.

Dr inż. Wojciech Tutak - adiunkt na Wydziale Inżynierii Mechanicznej i Informatyki Politechniki Częstochowskiej.

e-mail: tutak@imtits.pcz.czest.pl from a spark-ignition engine fueled with methanol. Fuel 89, 2010.

[9] Maiboom A., Tauzia X., Hétet J.: Experimental study of various effects of exhaust gas recirculation (EGR) on combustion and emissions of an automotive direct injection diesel engine. Energy, Vol. 33, Issue 1, 2008.

[10] Sasaki S., Sawada D., Ueda T., Sami H.: Effects of EGR on direct injection gasoline engine, JSAE Review 19, 1998.

[11] Szwaja S.: Combustion Knock - Heat Release Rate Correlation of a Hydrogen Fueled IC Engine Work Cycles, 9th International Conference on Heat Engines and Environmental Protection. Proceedings. Balatonfured, , s. 83-88, Hungary 2009.

[12] Tutak W.: Interpretacja wyników pomiaru prędkości przepływu ładunku w komorze spalania tłokowego silnika spalinowego. Pomiary Automatyka Kontrola, vol. 54, nr 2, 2008.

[13] Tutak W., Jamrozik A., Kociszewski A.: Three Dimensional Modelling of Combustion Process in SI Engine with Exhaust Gas Recirculation. Proceedings of 10th International Conference on Heat Engines and Environmental Protection, Balatonfüred, Hungary 2011.

[14] Tutak W.: Numerical analysis of some parameters of SI internal combustion engine with exhaust gas recirculation. TEKA PAN, Lublin 2011.

[15] Tutak W.: Numerical analysis of the impact of EGR on the knock limit in SI test engine. TEKA PAN, Lublin 2011.

[16] Tutak W.: Thermal Cycle of Engine Modeling with Initial Swirl Process Into Consideration, Combustion Engines 1/2008 (132), 2008.

[17] Yamin J.A.A., Gupta H.N., Bansal B.B., Srivastava O.N.: Effect of combustion duration on the performance and emission characteristics of a spark ignition engine using hydrogen as a fuel. International Journal of Hydrogen Energy 25, 2000. 